\title{
青森県上北平野で掘削された中期更新世後半以降の 風成堆積物のテフラ層序
}

\begin{abstract}
桑原拓一郎 $1, *$
Takuichiro Kuwabara (2010) Tephrostratigraphy of late middle Pleistocene to Holocene eolian deposits in drill cores recovered from the Kamikita Plain, Northeast Japan. Bull. Geol. Surv. Japan, vol. 61 (11/12), p.489-494, 2 figs, 2 tables.
\end{abstract}

Keywords: Quaternary, drill core, tephra, Aomori Prefecture, Japan

\section{1. はじめに}

青森県東部の上北平野の南部と北部に打いて（第1 図), 中期更新世後半に形成された七古段丘（宮内, 1985，1988；桑原，2004など）の構成物を被覆する延 長約 $25 \mathrm{~m}$ と $11 \mathrm{~m}$ の風成堆積物の柱状試料 2 本（それぞ れコア $1 ， 2$ と呼ぶ）が採取された。両コアとも，既に 植物珪酸体分析に供されて古気候の变遷が復元され, 海 洋酸素同位体比ステージ9（300-337 ka; Lisiecki and Raymo, 2005) 以降の各ステージとの対比が明らかにさ れた (桑原, 2009). しかしながら, これまで, 両コア

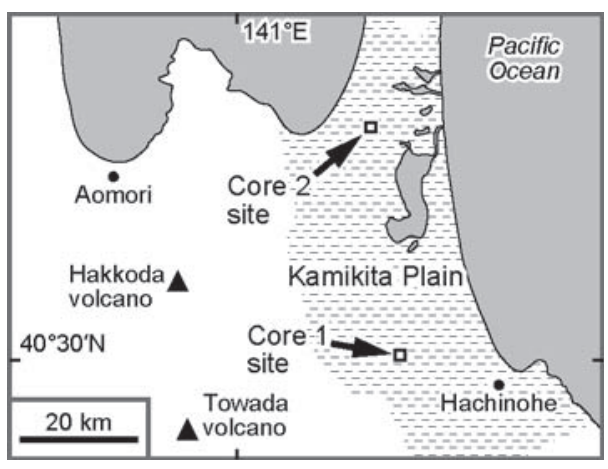

第 1 困掘削地点 (コア 1 , 北緯 $40^{\circ} 32^{\prime} 50^{\prime \prime}$, 東経 $141^{\circ}$ $18^{\prime} 1^{\prime \prime}$; コア 2 , 北緯 $40^{\circ} 53^{\prime} 6^{\prime \prime}$, 東経 $141^{\circ} 14^{\prime} 28^{\prime \prime}$ ). 掘削地点を含む地形図は, 桑原（2009）を参照さ れたい。

Fig. 1 Drilling sites (Core 1, 40 $32^{\prime} 50^{\prime \prime} \mathrm{N}, 141^{\circ} 18^{\prime} 1^{\prime \prime} \mathrm{E}$; Core 2, $\left.40^{\circ} 53^{\prime} 6^{\prime \prime} \mathrm{N}, 141^{\circ} 14^{\prime} 28^{\prime \prime} \mathrm{E}\right)$.

Detailed topographic maps showing the drilling sites are referred to Kuwabara (2009).
のテフラ層序については, その概要が報告されるものの, 各テフラ層の同定の根拠となる層位と層相の詳細並びに 岩石記載的特徵は明らかにされなかった（桑原，2009）.

上北平野には, 中期更新世以降の多数のテフラ層が分 布する (中川，1961; 東北地方第四紀研究グループ, 1969 など)。これらテフラ層については，それらの大部 分が八甲田及び十和田火山起源とみられ（岩崎，1983； Hayakawa, 1985 ; 松山・大池, 1986 ; 町田・新井, 2003 など), また同平野に分布する海成及び河成の段丘 との層位関係も把握されている（宮内，1985，1988； 桑原，2004など). したがって, 中期更新世以降の八甲 田や十和田火山に打ける各噴火の年代や上北平野に打け る各段丘の年代を検討する上で，海洋酸素同位体比ス テージとの対比がほぼ確実な両コアに扎いて，各テフラ 層の同定とそれらの根拠が注目される.

そこで, 両コアのテフラ層序について, 各テフラ層の 層位と層相の詳細, 並びに鉱物粒子の屈折率と化学組成 を含む岩石記載的特徵を明らかにし，今後の利用のため の一資料としたい。

\section{2. 掘削の概要}

両コアは，ロータリー式バイブロ工法（パーカッショ ン機）を用いて，七百段丘上（宮内，1985，1988; 桑原， 2004 など）で鉛直に掘削された（第 1 図）。全層準にわ たり直径 $69 \mathrm{~mm}$ ，無水掘で採取された。掘削時に伸縮を 受けている可能性があるが, その程度が不明であるため, 層厚に対してその補正はなされていない.コア 1 は, 上 北平野南部の三戸郡五戸町鹿内の畑作地で掘削され，孔 口標高は $114 \mathrm{~m}$ である.コア 2 は，上北平野北部の上北

地質情報研究部門（AIST, Geological Survey of Japan, Institute of Geology and Geoinformation)

*Corresponding autor: T. KUWABARA, Email: yiy06722@nifty.com

現連絡先：市川市鬼高 2-11-12-118 (Present address: Onitaka 2-11-12-118, Ichikawa, Chiba 272-0015, Japan) 
郡東北町豊畑の牧草地で掘削され，孔口標高は $90 \mathrm{~m}$ ある。

\section{3. 試料処理の概要}

層相に基づいて採取したテフラ試料に対して，まず， ナイロン製使い捨て $\# 255$ メッシュシートを用いて流水 中で洗浄してから，残砂を\#125メッシュシートを用い て水中で篩い分けした。 これにより $1 / 8 \sim 1 / 16 \mathrm{~mm}$ 粒度調整した試料に対して，超音波洗浄機を用いて鉱物 粒子の表面に付着した粘土分などを除去した。そして， 洗浄と篩い分けを行った乾燥試料に対して，偏光顕微鏡 （100倍）を用いて観察して，主要な重鉱物の個数の大 小や火山ガラスの形態ごとの有無などを記載した.更に, 火山ガラスと主要重鉱物を中心に，温度変化型屈折率測 定装置（古澤地質社製MAIOT）を用いて屈折率を測定 した. 1 試料当たりの測定粒子の個数の目処は，火山ガ ラスで 30 片，各重鉱物でそれぞれ 10 片である。測定值 にバラツキがある試料では，適宜に測定粒子を増やして モードを把握できるまで測定した。また，広域テフラ 2 試料の火山ガラスに対して, 走査電子顕微鏡 (HITACHI $\mathrm{S} 3000 \mathrm{H})$ とエネルギー分散型X線分析装置（HORIBA EMAX ENERGY EX-250) を用いて主成分の化学組成 を測定した。測定条件は，加速電圧：15 kV 及び試料電 流:0.3 nAである. 標準試料を用いた ZAF補正を行った. 1 試料当たりの測定粒子の個数の目処は，15片である.

\section{4. テフラ層序}

両コアから 23 枚のテフラ層が同定された（第 2 図, 第1表)。各テフラ層の名称は, 桑原 (2009) を踏襲して, 中期更新世のテフラ層については岩崎（1983）と松山・ 大池（1986）を，後期更新世以降のテフラ層について は町田・新井（2003）を参考とした。 以下，下位のテ フラ層から順番に，それらの層位と層相並びに岩石記載 的特徴についてまとめる。各テフラ層の特徵は，これら 既存の報告とは，打打むね矛盾はしていない.

\section{地蔵平テフラ, Jzd}

本層は，コア 1 で七百段丘構成物の上位約 $345 \mathrm{~cm}$ 付 近に認められる黒雲母の含有帯である.

\section{尔狗笜1テフラ, TE1}

本層は，コア 1 で $\mathrm{Jzd}$ の上位約 $50 \mathrm{~cm}$ に認められる層 厚約 $10 \mathrm{~cm}$ の橙色軽石層である。ここでは，軽石の平均 的な粒径は $1 \sim 2 \mathrm{~mm}$ である. 磁鉄鉱などの不透明鉱物 のほかに，斜方輝石と単斜輝石を含む.

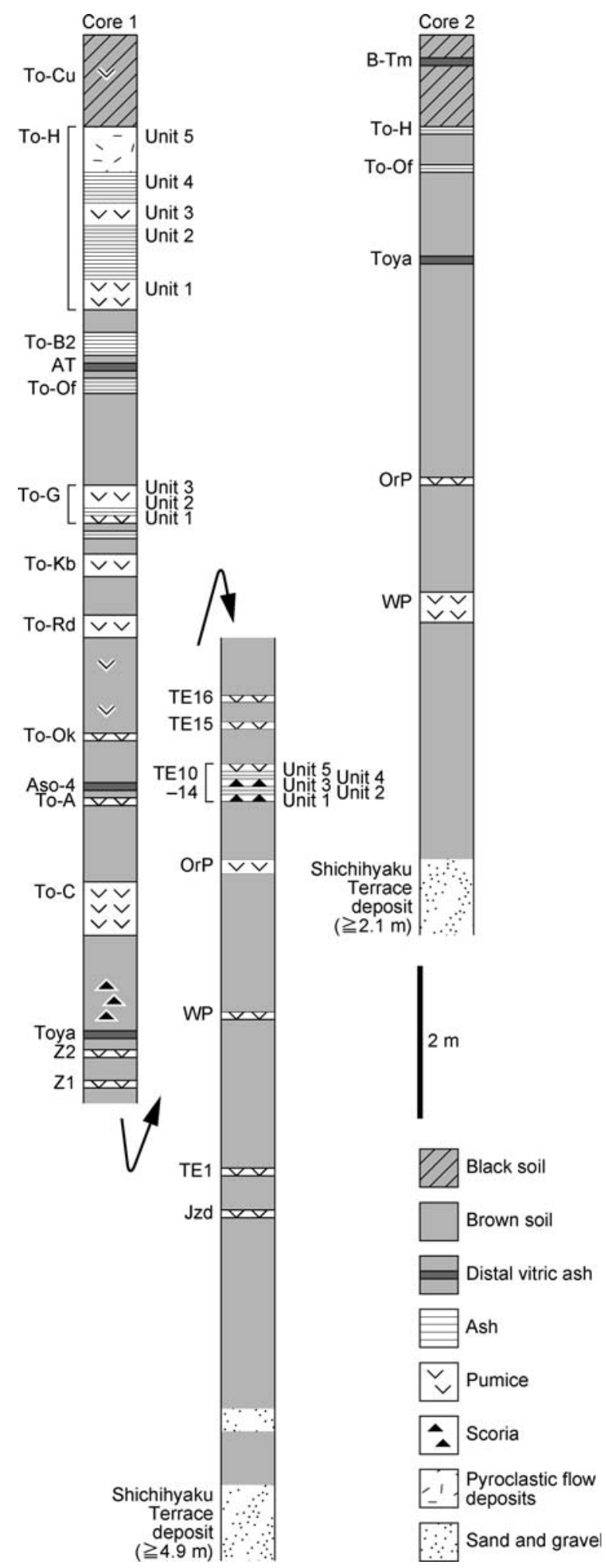

第 2 四 地質柱状図。 桑原（2009）の地質柱状困に加筆.

Fig. 2 Geologic columns.

Modified from the geologic columns in Kuwabara (2009). 
第 1 表 テフラ層の特徵.

Table 1 Characteristics of tephra layers.

\begin{tabular}{|c|c|c|c|c|c|c|c|c|c|c|c|}
\hline Tephra & & & Material & Color & $\begin{array}{l}\text { Thick- } \\
\text { ness } \\
(\mathrm{cm})\end{array}$ & $\begin{array}{l}\text { Grain } \\
\text { size } \\
(\mathrm{mm})\end{array}$ & $\begin{array}{l}\text { Heavy- } \\
\text { mineral } \\
\text { composition }\end{array}$ & $\begin{array}{l}\mathrm{Gl} \\
\text { Type }\end{array}$ & $\mathrm{n}$ & $\begin{array}{l}\text { Opx } \\
\gamma\end{array}$ & $\begin{array}{l}\mathrm{Hb} \\
\mathrm{n}_{2}\end{array}$ \\
\hline B-Tm & Core 2 & & scattered & & & & & $\mathrm{Pm}, \mathrm{Bw}$ & $1.518-1.519$ & & \\
\hline $\mathrm{To}-\mathrm{Cu}$ & Core 1 & & pumice & orange & $\sim 25$ & $1-2$ & Opx $>C p x$ & $\mathrm{Pm}$ & $1.506-1.520$ & $1.699-1.712$ & \\
\hline \multirow[t]{6}{*}{ To-H } & Core 1 & Unit 5 & $\begin{array}{l}\text { pyroclastic flow } \\
\text { deposits }\end{array}$ & orange & 60 & $<13$ & Opx,Cpx & $\mathrm{Pm}$ & $1.504-1.514$ & $1.705-1.711$ & \\
\hline & & Unit 4 & ash & orange & 40 & $<1$ & & $\mathrm{Pm}$ & $1.503-1.516$ & & \\
\hline & & Unit 3 & pumice & white & 30 & 4 & Opx & $\mathrm{Pm}$ & $1.504-1.517$ & $1.705-1.711$ & \\
\hline & & Unit 2 & ash & white & 80 & $<1$ & Opx,Cpx & $\mathrm{Pm}$ & $1.503-1.516$ & $1.704-1.710$ & \\
\hline & & Unit 1 & pumice & gray & 40 & $1-2$ & Opx & $\mathrm{Pm}$ & $1.506-1.518$ & $1.703-1.710$ & \\
\hline & Core 2 & & ash & orange & 35 & $<1$ & & $\mathrm{Pm}$ & $1.501-1.509$ & & \\
\hline To-B2 & Core 1 & & ash & brown & 35 & $<1$ & Opx & $\mathrm{Pm}$ & $1.506-1.518$ & $1.706-1.719$ & \\
\hline AT & Core 1 & & scattered & & & & & $\mathrm{Bw}$ & $1.499-1.501$ & & \\
\hline \multirow[t]{2}{*}{ To-Of } & Core 1 & & ash & orange & 35 & $<1$ & Opx & $\mathrm{Pm}$ & $1.504-1.516$ & $1.706-1.715$ & \\
\hline & Core 2 & & ash & brown & 20 & $<1$ & & $\mathrm{Pm}$ & $1.504-1.510$ & & \\
\hline \multirow[t]{3}{*}{ To-G } & Core 1 & Unit 3 & pumice & orange & 45 & $5-8$ & & $\mathrm{Pm}$ & $1.513-1.516$ & & \\
\hline & & Unit 2 & ash & orange & 15 & $<1$ & Opx,Cpx & $\mathrm{Pm}$ & $1.513-1.517$ & $1.705-1.711$ & \\
\hline & & Unit 1 & pumice & orange & 5 & $1-2$ & Opx,Cpx & $\mathrm{Pm}$ & $1.514-1.517$ & $1.706-1.710$ & \\
\hline To-Kb & Core 1 & & pumice & brown & 50 & $1-2$ & Opx $>C p x$ & $\mathrm{Pm}$ & $1.513-1.525$ & $1.706-1.712$ & \\
\hline To-Rd & Core 1 & & pumice & orange & 40 & n.d. & Opx,Cpx & & & $1.706-1.712$ & \\
\hline To-Ok & Core 1 & & pumice & yellow & 15 & n.d. & $\mathrm{Opx}>\mathrm{Cpx}$ & & & $1.708-1.712$ & \\
\hline Aso-4 & Core 1 & & scattered & & & & & Bw & $1.506-1.509$ & & \\
\hline To-A & Core 1 & & pumice & orange & 5 & n.d. & Cpx>Opx & $\mathrm{Pm}$ & $1.495-1.520$ & $1.705-1.716$ & \\
\hline To-C & Core 1 & & pumice & orange & 80 & 2 & $\mathrm{Cpx}>\mathrm{Opx}$ & & & $1.704-1.708$ & \\
\hline \multirow[t]{2}{*}{ Toya } & Core 1 & & ash & white & 10 & $<1$ & Opx,Cpx & $\mathrm{Pm}, \mathrm{Bw}$ & $1.495-1.500$ & $1.706-1.717$ & \\
\hline & Core 2 & & scattered & & & & & $\mathrm{Pm}, \mathrm{Bw}$ & $1.494-1.499$ & & \\
\hline Z2 & Core 1 & & pumice & white & 15 & $1-2$ & $\mathrm{Cpx}>\mathrm{Opx}$ & & & $1.707-1.716$ & \\
\hline Z1 & Core 1 & & pumice & white & 5 & $1-2$ & $\mathrm{Cpx}>\mathrm{Opx}$ & & & $1.707-1.712$ & \\
\hline TE16 & Core 1 & & pumice & white & 20 & n.d. & $\mathrm{Opx}>\mathrm{Cpx}>\mathrm{Hb}$ & & & $1.703-1.711$ & \\
\hline TE15 & Core 1 & & pumice & orange & 15 & 2 & $\mathrm{Opx}>\mathrm{Cpx}, \mathrm{Hb}$ & $\mathrm{Pm}$ & $1.499-1.504$ & $1.713-1.725$ & $\begin{array}{l}1.676-1.679 \\
1.685-1.691\end{array}$ \\
\hline \multirow[t]{5}{*}{ TE10-14 } & Core 1 & Unit 5 & pumice & orange & 10 & n.d. & $\mathrm{Hb}>>O p x$ & & & $\begin{array}{l}1.700-1.705 \\
1.715-1.725\end{array}$ & $1.675-1.681$ \\
\hline & & Unit 4 & ash & brown & 10 & $<1$ & $\mathrm{Hb}>\mathrm{Opx}$ & & & $1.699-1.724$ & $1.673-1.680$ \\
\hline & & Unit 3 & scoria & yellow & 10 & 1 & Opx>>Cpx,Hb & & & & \\
\hline & & Unit 2 & ash & white & 5 & $<1$ & Opx & & & & \\
\hline & & Unit 1 & scoria & black & 10 & 1 & $C p x>>O p x$ & & & & \\
\hline \multirow[t]{2}{*}{ OrP } & Core 1 & & pumice & orange & 30 & $1-2$ & $\mathrm{Opx}, \mathrm{Cpx}, \mathrm{Hb}$ & & & $1.702-1.712$ & $1.675-1.686$ \\
\hline & Core 2 & & pumice & orange & 30 & 1 & $\mathrm{Hb}>>\mathrm{Opx}$ & & & $1.699-1.710$ & $1.674-1.682$ \\
\hline \multirow[t]{2}{*}{ WP } & Core 1 & & pumice & orange & 25 & n.d. & Opx,Cpx & & & $1.699-1.710$ & \\
\hline & Core 2 & & pumice & orange & 70 & n.d. & Opx & & & $1.706-1.711$ & \\
\hline TE1 & Core 1 & & pumice & orange & 10 & $1-2$ & $\mathrm{Cpx}>\mathrm{Opx}$ & & & & \\
\hline Jzd & Core 1 & & scattered & & & & $\mathrm{Bt}$ & & & & \\
\hline
\end{tabular}

(n.d.) not determined, (Gl) volcanic glass, (Bw) bubble-wall type, (Pm) pumice type, (Opx) orthopyroxene, (Cpx) clinopyroxene, (Hb) hornblende, and (Bt) biotite.

白ベタテフラ, WP

本層は，両コアで認められる，コア1では，TE1の上 位約 $195 \mathrm{~cm}$ に認められる層厚約 $25 \mathrm{~cm}$ の橙色軽石層で ある.コア 2 では，七百段丘構成物の上位約 $285 \mathrm{~cm} に$ 認められる層厚約 $70 \mathrm{~cm}$ の橙色軽石層である. 両コアで, 風化により軽石は粘土状である. 不透明鉱物のほかに, 斜方輝石（ $\gamma=1.699-1.711 ）$ と単斜輝石を含む.

\section{オレンジテフラ, OrP}

本層は, 両コアで認められる. コア1では, WPの上 位約 $160 \mathrm{~cm}$ に認められる層厚約 $30 \mathrm{~cm}$ の橙色軽石層で ある.ここでは, 軽石の平均的な粒径は $1 \sim 2 \mathrm{~mm}$ である. コア 2 では, WPの上位約 $115 \mathrm{~cm}$ に認められる層厚約 $30 \mathrm{~cm}$ の橙色軽石層である.ここでは, 軽石の平均的な 粒径は $1 \mathrm{~mm}$ である. 両コアで，不透明鉱物のほかに， 斜方輝石 $(\gamma=1.699-1.712)$, 単斜輝石, そして角閃石 $\left(\mathrm{n}_{2}=1.674-1.686\right)$ を含む. 
天狗岱 $10 \sim 14$ テフラ, TE10 14

本層は，コア1で $\mathrm{OrP}$ の上位約 $75 \mathrm{~cm}$ に認められる層 厚約 $45 \mathrm{~cm}$ のテフラ層である.ここでは, 下位より, 黒 色スコリア層（ユニット 1), 白色細粒火山灰層 (ユニッ ト2)，黄色スコリア層（ユニット3），茶色細粒火山灰 層（ユニット4), そして橙色軽石層（ユニット5）より 成る. ユニット 1 と 3 は, スコリアの平均的な粒径はい ずれも $1 \mathrm{~mm}$ である。ユニット 5 は，風化により軽石は 粘土状である。これらのユニットで，不透明鉱物のほか に, 斜方輝石 $(\gamma=1.699-1.725)$, 単斜輝石，そして角 閃石 $\left(\mathrm{n}_{2}=1.673-1.681\right)$ を含む. ユニット $1 \sim 3$ で斜 方輝石と単斜輝石が優勢, ユニット $4 \sim 5$ で角閃石が優 勢である.

\section{天狗岱 15 テフラ, TE15}

本層は, コア 1 で TE10〜 14 の上位約 $45 \mathrm{~cm}$ に認めら れる層厚約 $15 \mathrm{~cm}$ の橙色軽石層である.ここでは，軽石 の平均的な粒径は $2 \mathrm{~mm}$ である. 不透明鉱物のほかに, 斜方輝石 $(\gamma=1.713-1.725)$, 単斜輝石，そして角閃石 $\left(\mathrm{n}_{2}=1.676-1.679,1.685-1.691\right)$ を含む. 軽石型の火山 ガラス $(\mathrm{n}=1.499-1.504)$ を含む.

\section{天狗岱 16 テフラ, TE16}

本層は，コア1でTE15の上位約 $15 \mathrm{~cm}$ に認められる 層厚約 $20 \mathrm{~cm}$ の白色軽石層である.ここでは，風化によ り軽石は粘土状である. 不透明鉱物のほかに, 斜方輝石 $(\gamma=1.703-1.711)$ と単斜輝石を含む. 微量ながら, 角 閃石も認められる.

\section{ザラメ1 テフラ, Z1}

本層は，コア 1 でTE16の上位約 $95 \mathrm{~cm}$ に認められる 層厚約 $5 \mathrm{~cm}$ の白色軽石層である。ここでは, 軽石の平 均的な粒径は $1 \sim 2 \mathrm{~mm}$ である. 不透明鉱物のほかに, 斜方輝石（ $\gamma=1.707-1.712 ）$ と単斜輝石を含む.

\section{ザラメ 2テフラ, Z2}

本層は，コア 1 で $\mathrm{Z} 1$ の上位約 $25 \mathrm{~cm}$ に認められる層
厚約 $15 \mathrm{~cm}$ の白色軽石層である.ここでは, 軽石の平均 的な粒径は $1 \sim 2 \mathrm{~mm}$ である. 不透明鉱物のほかに, 斜 方輝石（ $\gamma=1.707-1.716 ）$ と単斜輝石を含む.

\section{洞爺テフラ, Toya}

本層は，両コアで認められる.コア1では，Z20上 位約 $20 \mathrm{~cm}$ に認められる層厚約 $10 \mathrm{~cm}$ の白色細粒火山灰 層である.ここでは, 不透明鉱物のほかに, 斜方輝石（ $\gamma$ =1.706-1.717） と単斜輝石を含む. コア 2 では, OrP の上位約 $280 \mathrm{~cm}$ 付近に認められる火山ガラスの含有帯 である. 両コアで, 軽石型とバブル・ウォール型の火山 ガラス $(\mathrm{n}=1.494-1.500)$ を産出する.

\section{十和田カステラテフラ, To-C}

本層は，コア1で Toyaの上位約 $120 \mathrm{~cm}$ に認められる 層厚約 $80 \mathrm{~cm}$ の橙色軽石層である.ここでは, 軽石の平 均的な粒径は $2 \mathrm{~mm}$ である. 不透明鉱物のほかに, 斜方 輝石（ $\gamma=1.704-1.708 ）$ と単斜輝石を含む.

\section{十和田アオスジテフラ, To-A}

本層は，コア 1 でTo-Cの上位約 $90 \mathrm{~cm}$ に認められる 層厚約 $5 \mathrm{~cm}$ の橙色軽石層である。ここでは，風化によ り軽石は粘土状である。不透明鉱物のほかに，斜方輝石 $(\gamma=1.705-1.716)$ と単斜輝石を含む. 軽石型の火山ガ ラス $(\mathrm{n}=1.495-1.520)$ を含む.

\section{阿蘇 4 テフラ, Aso-4}

本層は，コア 1 で To-Aの上位約 $15 \mathrm{~cm}$ 付近に認めら れる火山ガラスの含有帯である。ここでは，バブル． ウォール型の火山ガラス $(\mathrm{n}=1.506-1.509)$ を産出する. 火山ガラスの主成分は, $\mathrm{SiO}_{2}: 72.72 \%, \mathrm{TiO}_{2}: 0.38 \%$, $\mathrm{Al}_{2} \mathrm{O}_{3}: 14.67 \%$, $\mathrm{FeO}: 1.47 \%, \mathrm{MnO}: 0.06 \%, \mathrm{MgO}: 0.38 \%$, $\mathrm{CaO}: 1.12 \%, \mathrm{Na}_{2} \mathrm{O}: 4.66 \%$ ，そして $\mathrm{K}_{2} \mathrm{O}: 4.54 \%$ ある (第 2 表).

\section{十和田オコシテフラ, To-Ok}

本層は，コア1でAso-4の上位約 $60 \mathrm{~cm}$ に認められる

第 2 表 火山ガラスの化学組成 (wt\%).

Table 2 Chemical compositions (wt $\%$ ) of volcanic glasses.

\begin{tabular}{lllllllllllll}
\hline Tephra & & $\mathrm{SiO}_{2}$ & $\mathrm{TiO}_{2}$ & $\mathrm{Al}_{2} \mathrm{O}_{3}$ & $\mathrm{FeO}$ & $\mathrm{MnO}$ & $\mathrm{MgO}$ & $\mathrm{CaO}$ & $\mathrm{Na}_{2} \mathrm{O}$ & $\mathrm{K}_{2} \mathrm{O}$ & $\mathrm{n}$ \\
\hline AT & Core 1 & 78.20 & 0.09 & 12.23 & 1.21 & 0.02 & 0.18 & 1.18 & 3.52 & 3.38 & 4 \\
& & 0.15 & 0.02 & 0.06 & 0.06 & 0.03 & 0.04 & 0.05 & 0.13 & 0.04 & \\
Aso-4 & Core 1 & 72.72 & 0.38 & 14.67 & 1.47 & 0.06 & 0.38 & 1.12 & 4.66 & 4.54 & 15 \\
& & 0.24 & 0.06 & 0.10 & 0.08 & 0.06 & 0.06 & 0.04 & 0.10 & 0.09 & \\
\hline
\end{tabular}

Analyses were recalculated to $100 \%$ in water-free and presented as means and standard deviations with $\mathrm{n}$ shards. 
層厚約 $15 \mathrm{~cm}$ の黄色軽石層である.ここでは, 風化によ り軽石は粘土状である。不透明鉱物のほかに，斜方輝石 $(\gamma=1.708-1.712)$ と単斜輝石を含む.

\section{十和田レッドテフラ, To-Rd}

本層は, コア 1 でTo-Okの上位約 $120 \mathrm{~cm}$ に認められ る層厚約 $40 \mathrm{~cm}$ の橙色軽石層である。ここでは，風化に より軽石は粘土状である. 不透明鉱物のほかに，斜方輝 石 $(\gamma=1.706-1.712)$ と単斜輝石を含む.

\section{十和田キビダンゴテフラ, To-Kb}

本層は, コア 1 でTo-Rdの上位約 $40 \mathrm{~cm}$ に認められる 層厚約 $50 \mathrm{~cm}$ の茶色軽石層である. ここでは, 軽石の平 均的な粒径は $1 \sim 2 \mathrm{~mm}$ である. 不透明鉱物のほかに, 斜方輝石 $(\gamma=1.706-1.712)$ と単斜輝石を含む. 軽石 型の火山ガラス $(\mathrm{n}=1.513-1.525)$ を含む.

\section{十和田合同テフラ, To-G}

本層は，コア 1 で To-Kbの上位約 $20 \mathrm{~cm}$ に認められる 層厚約 $65 \mathrm{~cm}$ のテフラ層である. ここでは, 下位より, 橙色軽石層（ユニット 1), 橙色細粒火山灰層（ユニッ ト2), そして橙色軽石層（ユニット3）より成る。ユニッ ト 1 と 3 は，軽石の平均的な粒径はそれぞれ $1 \sim 2 \mathrm{~mm}$ と $5 \sim 8 \mathrm{~mm}$ である. これらのユニットで，不透明鉱物 のほかに斜方輝石 $(\gamma=1.705-1.711)$ と単斜輝石を含む. 軽石型の火山ガラス（n=1.513-1.517）を含む.

\section{十和田大寺不動テフラ，To-Of}

本層は，両コアで認められる。 コア1では，To-Gの 上位約 $105 \mathrm{~cm}$ に認められる層厚約 $35 \mathrm{~cm}$ の橙色細粒火 山灰層である。ここでは，不透明鉱物のほかに斜方輝石 （ $\gamma=1.706-1.715 ）$ を含む. コア2では, Toyaの上位約 $100 \mathrm{~cm}$ に認められる層厚約 $20 \mathrm{~cm}$ の茶色細粒火山灰層 である. 両コアで, 軽石型の火山ガラス $(\mathrm{n}=1.504-1.516)$ を含む。

\section{姶良 Tnテフラ, AT}

本層は, コア 1 でTo-Ofの上位約 $15 \mathrm{~cm}$ 付近に認めら れる火山ガラスの含有帯である.ここでは，バブル． ウォール型の火山ガラス $(\mathrm{n}=1.499-1.501)$ を産出する. 火山ガラスの主成分は, $\mathrm{SiO}_{2}: 78.20 \%, \mathrm{TiO}_{2}: 0.09 \%$, $\mathrm{Al}_{2} \mathrm{O}_{3}: 12.23 \%$, $\mathrm{FeO}: 1.21 \%, \mathrm{MnO}: 0.02 \%, \mathrm{MgO}: 0.18 \%$,

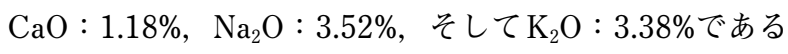
(第 2 表).

\section{十和田ビスケット2テフラ, To-B2}

本層は, コア 1 でATの上位約 $15 \mathrm{~cm}$ に認められる層 厚約 $35 \mathrm{~cm}$ の茶色細粒火山灰層である.ここでは，不透

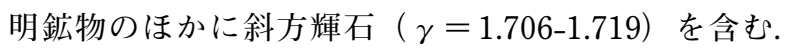

軽石型の火山ガラス（n=1.506-1.518）を含む.

\section{十和田八戸テフラ, To-H}

本層は，両コアで認められる. コア1では，To-B2の 上位約 $20 \mathrm{~cm}$ に認められる層厚約 $250 \mathrm{~cm}$ のテフラ層で ある，ここでは，下位より，灰色軽石層（ユニット 1), 白色細粒火山灰層（ユニット 2), 白色軽石層（ユニッ ト3), 橙色細粒火山灰層（ユニット4), そして橙色火 砕流堆積物（ユニット5）より成る.ユニット 1 と 3 は, 軽石の平均的な粒径はそれぞれ $1 \sim 2 \mathrm{~mm}$ と $4 \mathrm{~mm}$ である. ユニット 5 は, 軽石の粒径は $13 \mathrm{~mm}$ 未満である.これら のユニットで, 不透明鉱物のほかに斜方輝石 $(\gamma=$ 1.703-1.711）と単斜輝石を含む. コア2では，To-Ofの 上位約 $30 \mathrm{~cm}$ に認められる層厚約 $35 \mathrm{~cm}$ の橙色細粒火山 灰層である，両コアで，軽石型の火山ガラス $(\mathrm{n}=$ 1.501-1.518）を含む.

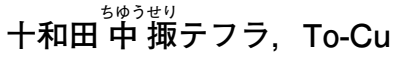

本層は, コア1で To-Hの上位約 $55 \mathrm{~cm}$ に認められる 層厚約 $25 \mathrm{~cm}$ の橙色軽石の含有帯である. ここでは, 軽 石の平均的な粒径は $1 \sim 2 \mathrm{~mm}$ である. 不透明鉱物のほ かに, 斜方輝石 $(\gamma=1.699-1.712)$ と単斜輝石を含む. 軽石型の火山ガラス $(\mathrm{n}=1.506-1.520)$ を含む. 本層の 上位約 $35 \mathrm{~cm}$ をもって, 地表面となる.

\section{热䫓究山苫小牧テフラ, B-Tm}

本層は, コア 2 でTo-Hの上位約 $80 \mathrm{~cm}$ 付近に認めら れる火山ガラスの含有带である. ここでは, 軽石型とバ ブル・ウォール型の火山ガラス $(\mathrm{n}=1.518-1.519)$ を産 出する. 本層の上位約 $25 \mathrm{~cm}$ をもって，地表面となる.

\section{5. まとめ}

上北平野の南部と北部で採取されたコア 1 と 2 から, 層位と層相並びに岩石記載的特徵に基づいて, 中期更新 世後半以降の 23 枚のテフラ層を同定した. 同定された テフラ層は, 下位より, Jzd, TE1, WP, OrP, TE10 〜 14, TE15, TE16, Z1, Z2, Toya, To-C, To-A, Aso-4, To-Ok, To-Rd, To-Kb, To-G, To-Of, AT, To-B2, To-H, To-Cu, そしてB-Tmである. これらの テフラ層のうち, WP, OrP, Toya, To-Of, そして To-Hが，両コアで同定された.

謝辞 : 山元孝広氏や伊藤順一氏をはじめとする深部地質 環境研究コアの方々から全面的な協力を得た. 試料処理 では，檀原 徹氏をはじめとする株式会社京都フィッ ション・トラックの方々，及び古澤 明氏をはじめとす る株式会社古澤地質の方々から協力を得た. 以上の方々 に，深く感謝します. 
試料処理は, 原子力安全基盤機構「平成 19 年度地層 処分に係る地質情報データの整備」及び原子力安全・保 安院「平成 20 年度地層処分に係る地質情報データの整 備」として実施した。

\section{文 献}

Hayakawa, Y. (1985) Pyroclastic geology of Towada volcano. Bulletin of the Earthquake Research Institute, University of Tokyo, 60, 507-592.

岩崎孝明 (1983) 青森県東部の火山灰. 駒沢大学大学 院地理学研究, no.13, 33-39.

桑原拓一郎 (2004) 青森県東部上北平野における海成 段丘構成物の層序と相対的海面変化. 地質学雑誌, 110, 93-102.

桑原拓一郎（2009）青森県上北平野で掘削された中期 更新世後半以降のテフラ一土㙵累積層の植物珪酸体 群集に基づく環境变遷と段丘との対比. 第四紀研究, 48, 405-416.

Lisiecki, L.E. and Raymo, M.E. (2005) A Pliocene-
Pleistocene stack of 57 globally distributed benthic $\delta^{18} \mathrm{O}$ records. Paleoceanography, 20, PA1003, doi:10.1029/2004PA001071.

町田 洋・新井房夫 (2003) 新編火山灰アトラス一日 本列島とその周辺一. 東京大学出版会, 336p.

松山 力 . 大池昭二 (1986) 十和田火山噴出物と火山 活動。十和田科學博物館, no.4, 1-64.

宮内崇裕 (1985) 上北平野の段丘と第四紀地殼変動. 地理学評論, 58A, 492-515.

宮内崇裕（1988）東北日本北部における後期更新世海 成面の対比と編年. 地理学評論，61A，404-422.

中川久夫（1961）本邦太平洋沿岸地方に打ける海水準 静的変化と第四紀編年. 東北大學理學部地質學古生 物學教室研究邦文報告, no.54，1-61.

東北地方第四紀研究グループ (1969) 東北地方におけ る第四紀海水準変化. 地学団体研究会専報, no.15, $37-83$.

(受付：2010年 1 月 20 日；受理：2010年 9 月 6 日) 